\title{
Association between internet addiction and suicidal ideation in university students
}

\author{
Associação entre dependência de internet e ideação suicida em estudantes universitários \\ Asociación entre la adicción a internet y la ideación suicida en estudiantes universitarios
}

Received: 04/26/2021 | Reviewed: 05/05/2021 | Accept: 05/07/2021 | Published: 05/22/2021

\author{
Irena Penha Duprat \\ ORCID: https://orcid.org/0000-0001-8273-4822 \\ Universidade de Ciências da Saúde de Alagoas, Brazil \\ Universidade de São Paulo, Brazil \\ E-mail: irena.duprat@uncisal.edu.br \\ Verônica de Medeiros Alves \\ ORCID: https://orcid.org/0000-0002-4343-2941 \\ Universidade Federal de Alagoas. Brazil \\ E-mail: veronica.alves@eenf.ufal.br \\ Janine Melo de Oliveira \\ ORCID: https://orcid.org/0000-0002-8816-2244 \\ Universidade de Ciências da Saúde de Alagoas. Brazil \\ E-mail: veronica.alves@eenf.ufal.br \\ Frida Marina Fischer \\ ORCID: https://orcid.org/0000-0001-9403-6300 \\ Universidade de São Paulo, Brazil \\ E-mail: fmfische@usp.br
}

\begin{abstract}
Objective: to investigate the evidence in the literature on the association between internet addiction and suicidal ideation in university students. Method: an integrative review of publications on the CINAHL, EMBASE, LILACS, MEDLINE, PubMed, PsycInfo, SciELO, SCOPUS, Web of Science and Biblioteca Virtual em Saúde databases was carried out, without restrictions regarding language or publication date. The final sample comprised 5 articles, which were organized and characterized according to author, year, method, sample, country, instruments and results. Results: the prevalence of internet addiction among university students ranged from $7.7 \%$ to $27.3 \%$, and suicidal ideation from $7.4 \%$ to $36.1 \%$. The results of simple logistic regression analyses showed a significant association between internet addiction and suicidal ideation, although on multiple logistic regression this association was not statistically significant for 2 out of the 5 studies reviewed. Subjects at risk of or with addiction to the internet had a significantly higher rate of suicidal ideation compared with controls. Conclusion: although the presence of association does not indicate causality, these findings serve as an early warning sign to parents, educators and health professionals, indicating the need for longitudinal studies to further elucidate this relationship.
\end{abstract}

Keywords: Students; Internet: Suicidal ideation; Behavior.

\section{Resumo}

Objetivo: investigar quais são as evidências publicadas sobre a associação entre dependência de Internet e ideação suicida em estudantes universitários. Método: revisão integrativa realizada nas fontes de dados CINAHL, EMBASE, LILACS, MEDLINE, PubMed, PsycInfo, SciELO, SCOPUS, Web of Science e Biblioteca Virtual em Saúde. sem restrição de idioma e de data de publicação. A amostra foi composta por 5 artigos, organizados e caracterizados de acordo com autor, ano, método, amostra, local do estudo, instrumentos e resultados. Resultados: a taxa de prevalência de dependência de internet nos estudantes universitários variou entre 7,7\% a 27,3\% e de ideação suicida variou de 7,4\% a 36,1\%. Houve uma associação significativa entre dependência de Internet e ideação suicida nos resultados de análises de regressão logística simples, mas com regressão logística múltipla essa associação não foi estatisticamente significativa em dois dos cinco estudos. Sujeitos com risco ou dependentes da Internet tiveram níveis significativamente mais elevados de ideação suicida em comparação com os controles. Conclusão: embora a presença de associação não signifique causalidade, os achados fornecem um sinal de alerta precoce que merece atenção especial de pais, profissionais de educação e da saúde e apontam para a necessidade de pesquisas longitudinais para melhor esclarecer essa relação.

Palavras-chave: Estudantes; Internet; Ideação suicida; Comportamento.

\section{Resumen}

Objetivo: investigar la evidencia en la literatura sobre la asociación entre adicción a internet e ideación suicida en estudiantes universitarios. Método: revisión integrativa realizada en las fuentes de datos CINAHL, EMBASE, LILACS, MEDLINE, PubMed, PsycInfo, SciELO, SCOPUS, Web of Science y Virtual Health Library. sin restricción de idioma 
y fecha de publicación. La muestra final consistió en 5 artículos, organizados y caracterizados según autor, año, método, muestra, país de estudio, instrumentos y resultados. Resultados: la tasa de prevalencia de la dependencia de Internet en los estudiantes universitarios osciló entre el 7,7\% y el 27,3\% y la ideación suicida osciló entre el 7,4\% y el 36,1\%. Hubo una asociación significativa entre la dependencia de Internet y la ideación suicida en los resultados de simples análisis de regresión logística. No obstante, bajo múltiples regresionón logística, esta asociación no fue estadísticamente significativa en dos de los cinco estudios. Los sujetos en riesgo o dependientes de Internet tenían niveles significativamente más altos de ideación suicida en comparación con los controles. Conclusión: aunque la presencia de asociación no indica causalidad, estos hallazgos sirven como una señal de alerta temprana para padres, educadores y profesionales de la salud, indicando la necesidad de estudios longitudinales para dilucidar aún más esta relación.

Palabras clave: Estudiantes; Internet; Ideación suicida; Comportamiento.

\section{Introduction}

Internet use has soared 1,239\% over the last 20 years. According to estimates for the second half of 2020, there are over 4.8 billion $(4,833,521,000)$ active internet users worldwide, encompassing $62.0 \%$ of the global population. North America and Africa are the regions with the highest (90.3\%) and lowest (42.2\%) internet penetration rates, respectively (Internet World Stats, 2020a). In South America, there are around 306,349,946 internet users (74.8\% of total population). Brazil has 149,057,635 users (70.1\% penetration) and is ranked seventh for internet usage among the countries of South America (Internet World Stats, 2020b).

Despite the numerous benefits of internet use (for communication, information searches, scientific research, social contact, new habits, affirmation of diversity and self-knowledge, a forum for gatherings, among others) (Fumero et al., 2018; Ibope, 2019), the long daily hours of interactivity over the internet can impact people's lives and promote significant changes in habits, behaviors, personal and social relationships, and may pose a danger to health (Ibope, 2019; King et al., 2019; Picon et al., 2015).

There is growing concern in the scientific community over the amount of time people spend immersed in a virtual world and the way this is dominating people's lives. The phenomenon is now recognized as an emerging mental disorder (Silva, 2016). Given the recency of the condition, a host of terms are in use with different definitions established.

Excessive use of the internet is defined as uncontrolled and prolonged use, to the point of having a major deleterious effect on the user's well-being (Kraut et al., 1998). Internet addiction is characterized by a non-adaptive pattern of internet use, leading to significant compromise or distress (Weinstein \& Lejoyeux, 2010). Although defined in a multitude of ways, these disorders are regarded as synonyms of internet addiction. Besides these definitions, other terms frequently used in the scientific literature include "problematic internet use", "technology addiction or dependence" and "pathological internet engagement", "compulsive internet use" and "internet abuse" (Silva, 2016; Ho et al., 2014).

Some studies have shown that internet use is greater among younger individuals aged 16-24 years. This suggests that university and high-school students are the group with the highest risk of addiction, i.e. "Generation Z", or those born since 1997, the first truly digital generation. Generation $\mathrm{Z}$ may be experiencing an even worse mental health crisis than that faced by the previous generation (Kiersz \& Akhtar, 2019).

According to some scholars, going to university, for instance, can give rise to crisis and favor the onset of mental disorders. In a bid to deal with problems passively, younger individuals often resort to spending long periods online as a strategy for avoiding their issues (Chen et al., 2017). As a result, these individuals can begin to develop symptoms of isolation and sometimes, depression (Liu et al., 2016; Younes et al., 2016), anxiety and sleep loss (Younes et al, 2016). These symptoms may worsen and increase the risk of suicidal behaviors (Centers for Disease Control and Prevention, 2019).

Adolescents and young adults have become a focus of governments owing to the rising number of deaths by suicide in recent years (World Health Organization, 2012), now constituting the second-leading cause of mortality in persons aged 15-29 years (Centers for Disease Control and Prevention, 2018).

There are numerous studies in the literature on internet addiction and its negative impact on key spheres of life 
(interpersonal relationship, physical and mental health, besides academic and work-related performance). Extensive research has been carried out investigating suicidal ideation and its association with a variety of risk factors, including mental disorders such as depression and anxiety. However, few studies have explored the association between internet addiction and suicidal ideation. The increasing accessibility and intensity of internet use, particularly among younger users, coupled with the fact that university students are a group vulnerable to internet addiction and suicidal behaviors, and that suicidal ideation can be a first step towards ending one's life, prompted the present study investigating the available literature on the association between internet addiction and suicidal ideation in university students.

\section{Methodology}

An integrative review of the scientific literature was carried out. The integrative review makes it possible to gather, synthesize and evaluate the results of research on delimited theme or question, in a systematic and orderly manner, contributing to the deepening of knowledge of the theme investigated, besides pointing out gaps in knowledge that need to be filled with new studies (Mendes, Silveira \& Galvão, 2008). It entailed six steps: (1) devising the overarching research question; (2) establishing study inclusion and exclusion criteria; (3) categorizing studies retrieved; (4) assessing studies included; (5) interpreting results; and (6) presenting the review (Mendes, Silveira \& Galvão, 2008).

The overarching research question was: "Is there an association between internet addiction and suicidal ideation in university students?". The research question was developed using the PICO framework (Santos et al., 2007) (acronym for patient, intervention, comparison, outcomes), where P represented the "population" (university students); I "intervention" (internet addiction); C "comparison" (not-applicable, since not a comparative study); and $\mathrm{O}$ "outcome" (suicidal ideation).

In order to maximize the number of articles retrieved, the following electronic databases were searched: Index to Nursing and Allied Health Literature (CINAHL), Excerpta Medica atabase (EMBASE), Literatura Latino-Americana e do Caribe em Ciências de Saúde (LILACS), Medical Literature Analysis and Retrieval System on-line (MEDLINE), Psychology Information (PsycInfo), SCOPUS and Web of Science; in addition to the libraries: Biblioteca Virtual em Saúde (BVS), Scientific Electronic Library Online (SciELO) and the National Center for Biotechnology Information (NCBI/PubMed).

The strategy employed for the literature search consisted of a combination of controlled descriptors and keywords, as per recommendations of each respective database, using the Boolean operators 'OR' and 'AND' (see Figure 1). The search was carried out between 1st and 31st of October, 2020. The search and selection of articles was performed by two reviewers independently. 
Figure 1 - Controlled descriptors and key words used with the PICO strategy and Boolean operators. Maceió, Alagoas state, Brazil, 2020

\begin{tabular}{|c|c|c|c|c|c|}
\hline Acronym & Content & LILACS & $\begin{array}{c}\text { BVS } \\
\text { PubMed, } \\
\text { SciELO, SCOPUS }\end{array}$ & EMBASE & $\begin{array}{c}\text { CINAHL } \\
\text { MEDLINE } \\
\text { PsycInfo } \\
\text { Web of Science }\end{array}$ \\
\hline \multirow[t]{2}{*}{$\mathrm{P}$} & $\begin{array}{l}\text { University } \\
\text { Students }\end{array}$ & $\begin{array}{l}\text { Estudantes / } \\
\text { students / } \\
\text { estudiantes }\end{array}$ & college students & $\begin{array}{l}\text { 'college student'/exp and } \\
\text { its synonyms }\end{array}$ & $\begin{array}{l}\text { college students OR university } \\
\text { students OR undergraduates } \\
\text { OR undergraduate students }\end{array}$ \\
\hline & & AND & AND & AND & AND \\
\hline I & $\begin{array}{c}\text { Internet } \\
\text { Addiction }\end{array}$ & $\begin{array}{l}\text { Internet / internet / } \\
\text { internet }\end{array}$ & internet addiction & $\begin{array}{l}\text { 'internet addiction'/exp } \\
\text { and its synonyms }\end{array}$ & $\begin{array}{c}\text { internet addiction OR excessive } \\
\text { internet use OR problematic } \\
\text { internet use OR social media } \\
\text { addiction }\end{array}$ \\
\hline \multirow[t]{2}{*}{$\mathrm{C}$} & - & - & - & - & - \\
\hline & & AND & AND & AND & AND \\
\hline $\mathrm{O}$ & $\begin{array}{l}\text { Suicidal } \\
\text { Ideation }\end{array}$ & $\begin{array}{l}\text { ideação suicida / } \\
\text { suicidal ideation / } \\
\text { ideación suicida }\end{array}$ & suicidal ideation & $\begin{array}{l}\text { 'suicidal ideation'/exp } \\
\text { and its synonyms }\end{array}$ & $\begin{array}{l}\text { suicide ideation OR suicidal } \\
\text { ideation OR suicidal thoughts }\end{array}$ \\
\hline
\end{tabular}

Source: Authors (2020).

The sample was selected based on the following inclusion criteria: article addresses the overarching research question, article is duly indexed on the databases searched with full text available, in any language and for any publication date. Publications that were meta-analyses, editorials, letters to the Editor, theses, dissertations, duplicate articles or off-topic were excluded from the review.

The article selection and eligibility process were performed according to the PRISMA (Preferred Reporting Items for Systematic Reviews and MetaAnalyses) statement (Brasil, 2012), adapted for the present integrative review.

After searching the databases, the studies retrieved were input to the EndNote Web reference management utility, which subsequently applied filters to exclude duplicate articles. All titles and abstracts were then read and articles addressing the overarching research question were selected for full reading. Lastly, the primary articles were selected by applying the previously defined inclusion criteria. Data analysis was performed using an instrument collecting information on the following fields: author, year, country, sample, instruments used, and results. This process was carried out to extract, organize and summarize the information and compile a database.

Level of evidence was defined as follows: level I, meta-analyses and randomized controlled trials; level II, experimental studies; level III, quasi-experimental studies; level IV, descriptive, non-experimental or qualitative studies; level V, case series/reports; and level VI, expert opinion and consensus (Melnyk \& Fineout-Overholt, 2015).

Findings were discussed in a descriptive manner, thereby allowing the reader to assess the applicability of the integrative review reported. The study was carried out in conformance with the legal and ethical principles provided for in Resolution 510/2016 by the National Board of Health involving studies of information in the public domain.

\section{Results}

The search led to the retrieval of 111 publications in total, of which 41 were excluded for being repeated and 51 for not satisfying the inclusion criteria, giving five studies for inclusion in the final sample. All of the studies included in the review were from international journals (see Figure 2). 
Figure 2 - Flow diagram of article search and selection process according to the PRISMA statement, adapted for the review. Maceió, Alagoas state, Brazil, 2020.
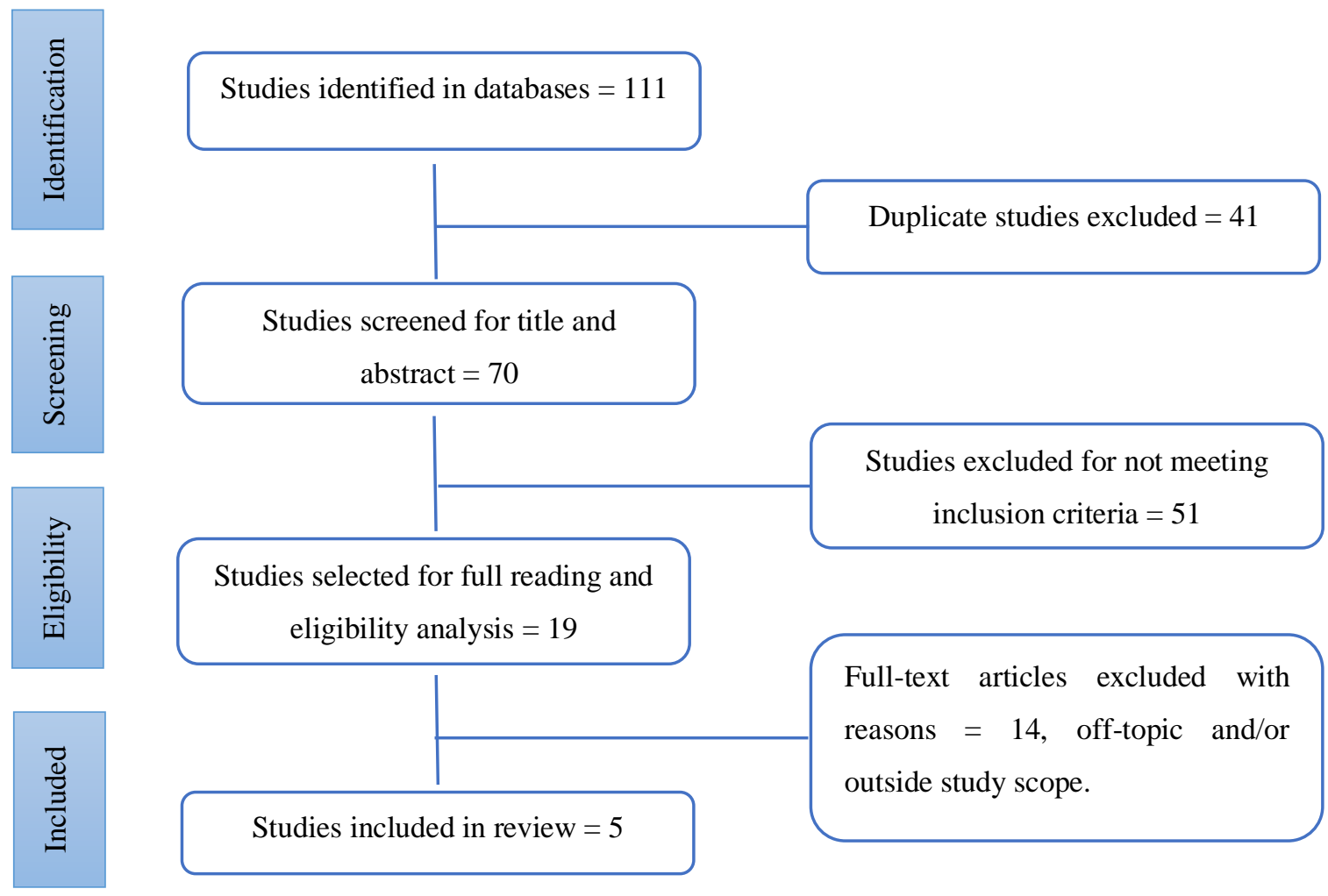

Source: Authors (2020).

The countries of origin of the publications were Greece, China, Iran and Mexico. The article publication dates were 2011, 2018, 2019. All articles had a quantitative, descriptive, cross-sectional design and level of evidence of IV, according to the classification used for analysis. The characteristics of the studies (authors, publication year, country, sample, instruments and results) are shown in Figure 3.

Figure 3 - Description of articles selected, including author, publication year, sample, country, instruments and results. Maceió, Alagoas state, Brazil, 2020.

\begin{tabular}{|c|c|c|c|c|}
\hline Article & $\begin{array}{c}\text { Author; } \\
\text { Country; Year }\end{array}$ & Sample & Instruments & Results \\
\hline A1 & $\begin{array}{l}\text { Jasso-Medrano } \\
\text { JL, Lopez- } \\
\text { Rosales F.; } \\
\text { Mexico; } 2018\end{array}$ & $\begin{array}{l}374 \text { university } \\
\text { students }(58.6 \% \\
\text { women, } 41.4 \% \\
\text { men). Mean age } \\
20.01 \text { years }(\mathrm{SD} \pm \\
1.84) .\end{array}$ & $\begin{array}{l}\text { - Social Network Addiction } \\
\text { Questionnaire (ARS); } \\
\text { - Positive and Negative Suicidal } \\
\text { Ideation Inventory (PANSI); } \\
\text { - Center for Epidemiologic Studies } \\
\text { Depression Scale (CES-D). }\end{array}$ & $\begin{array}{l}\text { Addictive behavior was significantly related to } \\
\text { depression suicidal ideation. } 36.1 \% \text { of the sample } \\
\text { reported having at least one idea in relation to } \\
\text { suicide in the last two weeks. }\end{array}$ \\
\hline A2 & $\begin{array}{l}\text { Poorolajal J et } \\
\text { al., Iran; } 2019\end{array}$ & $\begin{array}{l}4261 \text { university } \\
\text { students }(55.9 \% \\
\text { women, } 44.1 \% \\
\text { men). Mean age } \\
22.17 \text { years. }\end{array}$ & $\begin{array}{l}\text { - Problematic Internet Use } \\
\text { questionnaire (PIU-15); } \\
\text { - General Health Questionnaire } \\
\text { (GHQ-28). }\end{array}$ & $\begin{array}{l}\text { Based on the unadjusted model, there was a } \\
\text { significant association between problematic } \\
\text { internet use and suicidal ideation and attempt, } \\
\text { among other variables. However, on the adjusted } \\
\text { model, there was a significant association with } \\
\text { attempting suicide. }\end{array}$ \\
\hline A3 & $\begin{array}{l}\text { Poorolajal J et } \\
\text { al., Iran; } 2018\end{array}$ & $\begin{array}{l}4261 \text { university } \\
\text { students }(55.9 \% \\
\text { women, } 44.1 \% \\
\text { men). Mean age } \\
22.17 \text { years. }\end{array}$ & $\begin{array}{l}\text { - Internet Addiction Test (IAT-20); } \\
\text { - General Health Questionnaire } \\
\text { (GHQ-28). }\end{array}$ & $\begin{array}{l}\text { The prevalence of internet addiction was } 24.5 \% \text {, } \\
\text { suicidal ideation } 7.4 \% \text {, attempting suicide } 1.7 \% \text {. } \\
\text { Based on the results of simple logistic regression } \\
\text { analyses, there was a significant association } \\
\text { between suicidal ideation and all variables in the } \\
\text { table. However, according to the results of } \\
\text { multiple logistic regression, the association } \\
\text { between suicidal ideation and internet addiction } \\
\text { was not statistically significant. }\end{array}$ \\
\hline
\end{tabular}




\begin{tabular}{|c|c|c|c|c|}
\hline A4 & $\begin{array}{l}\text { Shen Y et al.; } \\
\text { China; } 2020\end{array}$ & $\begin{array}{l}8098 \text { university } \\
\text { students. } 3592 \text { were } \\
\text { women }(44.3 \%) \text { and } \\
4656 \text { men }(55.7 \%) \text {. } \\
\text { Mean age } 20.12 \\
\text { years. }\end{array}$ & $\begin{array}{l}\text { - Revised Chinese Internet Addiction } \\
\text { Scale (CIAS-R); } \\
\text { - Self-reporting depression and } \\
\text { anxiety scales. }\end{array}$ & $\begin{array}{l}\text { Internet addicts were more likely to experience } \\
\text { anxiety or depression, have suicidal ideation, } \\
\text { make suicide plans or attempts (p-<0.05) } \\
\text { compared with non-addicts. }\end{array}$ \\
\hline A5 & $\begin{array}{l}\text { Tsouvelas G, } \\
\text { Giotakos O.; } \\
\text { Greece; } 2011\end{array}$ & $\begin{array}{l}514 \text { university } \\
\text { students. } 278 \text { were } \\
\text { women }(54.1 \%) \text { and } \\
235 \text { men }(45.9 \%) . \\
\text { Mean age of } 22.46 \\
\text { years }(\mathrm{SD}=3.2) .\end{array}$ & - Internet Addiction Test (IAT-20). & $\begin{array}{l}\text { Subjects at risk for developing pathological } \\
\text { internet engagement had significantly higher } \\
\text { levels of online gambling addiction, cybersexual } \\
\text { addiction, suicidal ideation and alcohol abuse, } \\
\text { compared with other groups. }\end{array}$ \\
\hline
\end{tabular}

Source: Authors (2020).

The smallest sample comprised 374 university students (58.6\% women and $41.4 \%$ men), whereas the largest had 8098 students ( $44.3 \%$ women and $55.7 \%$ men). Mean age ranged from 20.01 to 22.46 years.

The primary studies selected used different instruments to determine the prevalence of internet addiction and suicidal ideation. The following instruments were used to measure internet addiction: Social Network Addiction Questionnaire (Cuestionario de Adicción a Redes Sociales - ARS) (A1) (Jasso-Medrano \& Lopez-Rosales, 2018); Problematic Internet Use questionnaire (PIU-15) (A2) (Poorolajal et al., 2019); Internet Addiction Test (IAT-20) (A3; A5) (Poorolajal et al., 2018; Tsouvelas \& Giotakos, 2011); Revised Chinese Internet Addiction Scale (CIAS-R) (A4) (Shen et al., 2020); Two studies also included questions devised by the authors on internet use (A1) (Jasso-Medrano \& Lopez-Rosales, 2018) and online gambling and cybersexual addiction (A5) (Tsouvelas \& Giotakos, 2011), respectively.

Suicidal ideation was assessed using the Positive and Negative Suicidal Ideation Inventory (Inventario de Ideacion Suicida Positiva y Negativa, PANSI) (A1) (Jasso-Medrano \& Lopez-Rosales, 2018) and questionnaires developed by the authors of the studies, containing questions investigating suicidal ideation (A2; A3; A4; A5) (Poorolajal et al., 2019; Poorolajal et al., 2018; Shen et al., 2020; Tsouvelas \& Giotakos, 2011).

Other instruments were also used for assessing variables correlated with internet addiction or suicidal addiction, such as: the Center for Epidemiologic Studies Depression Scale - CES-D) (A1) (Jasso-Medrano \& Lopez-Rosales, 2018); General Health Questionnaire - GHQ-28) (A2; A3) (Poorolajal et al., 2019; Poorolajal et al., 2018); Self-reporting Depression Scale SDS) (A4) (Shen et al., 2020) and Self-rating Anxiety Scale - SAS) (A4) (Shen et al., 2020); besides self-administered questionnaires for investigating risk-taking behaviors such as smoking, illicit drugs abuse, drinking alcohol, and risky unprotected sex (A3; A4) (Shen et al., 2020; Tsouvelas \& Giotakos, 2011).

The results of the studies also revealed that:

- The prevalence of internet addiction among university students ranged from 7.7\% (A4) (Shen et al., 2020) to $27.3 \%$ (A2) (Poorolajal et al., 2019).

- The prevalence of suicidal ideation ranged from 7.4\% (A2; A3) (Poorolajal et al., 2019; Poorolajal et al., 2018) to $36.1 \%$ (A1) (Jasso-Medrano \& Lopez-Rosales, 2018).

- The results of simple logistic regression showed a significant association between internet addiction and suicidal ideation in all the studies selected. However, according to the results of multiple logistic regression, the association between suicidal ideation and internet addiction was not statistically significant in 2 out of the 5 studies included in the review (A2; A3) (Poorolajal et al., 2019; Poorolajal et al., 2018).

- Addictive behavior, considered a subtype of internet addiction, was significantly associated with depression and suicidal ideation. In addition, addiction was considered a protective factor for suicidal ideation when cooccurring with depression, based on an adjusted theoretical model devised by the authors and analyzed using the equations modeling method (A1) (Jasso-Medrano \& Lopez-Rosales, 2018). 
- Subjects at risk of or having internet addiction had significantly higher rates of suicidal ideation compared with non-addicted groups (A1; A2; A4; A5) (Jasso-Medrano e Lopez-Rosales, 2018; Poorolajal et al., 2019; Shen et al., 2020; Tsouvelas \& Giotakos, 2011).

- The rate of attempted suicide among internet addicts was significantly greater than that in non-addicts (A2; A4) (Poorolajal et al., 2019; Shen et al., 2020). After controlling for confounding factors, suicidal ideation and suicide plans proved independent predictors of attempted suicide among internet addicts (A4) (Shen et al., 2020).

\section{Discussion}

Internet use is becoming increasingly important in acquiring information and for sharing knowledge (Kim et al., 2016), representing an essential part of people's everyday lives worldwide, particularly among the younger population. This use is by no means new, but there has been a shift in terms of increased intensity, accessibility and availability among users (Greenfield, 2011). This overuse, when linked to a craving for repeated use, has been characterized as "problematic internet use" and constitutes an emerging health problem that can lead to deleterious physical, emotional, social and functional effects (Moreno, Jelenchick \& Christalis, 2013; American Psychiatric Association, 2013).

The results of the primary studies comprising the sample of the present integrative review showed a prevalence of internet addiction ranging from $7.7 \%$ (A4) (Shen et al., 2020) to 27.3\% (A2) (Poorolajal et al., 2019). This range is similar to that found in studies estimating prevalence rate of problematic internet use among Chinese adolescents $(8.1 \%-27.5 \%)(\mathrm{Cao}$ et al., 2013; Huang et al., 2020). Other results in the literature are also consistent with the rates found in the studies reviewed, such as studies of university students in India (12.5\%) (Bisen e Deshpande, 2020) and Lebanon (16.8\%) (Younes et al., 2016) and of high-school students in South Korea (9.4\%) (Park et al., 2012), Spain (19.2\%) (Torrent et al., 2014) and China (26.5\%) (Xin et al., 2018).

Disparities in prevalence rates of internet addiction among countries might stem from the nature of the samples assessed (e.g. age or gender profiles) or their size. The wide variety of tools used for measuring this rate may also be a factor explaining the difference found.

The quality of the results found in studies is pivotal for researchers to interpret the data reported and draw meaningful conclusions from them. In order to assure this quality, the instruments employed for data collection should be validated and reliable, where such studies are key to showing the effectiveness of these instruments (Monteiro, 2013).

The prevalence rates of internet addiction in the primary studies reviewed were measured used different instruments, except for articles A3 (Poorolajal et al., 2018) and A5 (Tsouvelas \& Giotakos, 2011). These two studies employed the Internet Addiction Test (IAT-20) (Conti et al., 2012) - the most widely used test in the international literature, providing excellent sensitivity and reliability with validated versions available for many languages. The original IAT comprises 20 items rated on a 5-point Likert scale ranging from 1 (rarely) to 5 (always). Higher scores represent higher level of severity of internet addiction.

Article A1 (Jasso-Medrano \& Lopez-Rosales, 2018) used the Social Network Addiction questionnaire (ARS) (Mayaute e Blas, 2014), a 24-item tool designed to measure social media addiction in university students. According to the original study, the instrument measures 3 dimensions: Obsession, lack of personal control and excessive use, and is considered reliable, exhibiting excellent internal consistency. Article A2 (Poorolajal et al., 2019) used the Problematic Internet Use questionnaire (PIU-15) (Kelley \& Gruber, 2010), a screening tool assessing five subscales each containing 3 items. Total score ranges from 15 to 105, where a total score of 15-59 reflects normal internet use, while 60-105 represents problematic internet use. Article A4 (Shen et al., 2020) reported use of the Revised Chinese Internet Addiction Scale (CIAS-R) (Bai e Fan, 2005). The instrument 
comprises 19 self-reported items rated on a 4-point scale and has good reliability and validity. Total score on the scale ranges from 0 to 76. Participants scoring over 53 points are diagnosed as having an internet addiction.

The prevalence of suicidal ideation among university students reported by the studies reviewed ranges from 7.4\% (A2; A3) (Poorolajal et al., 2019; Poorolajal et al., 2018) to 36.1\% (A1) (Jasso-Medrano \& Lopez-Rosales, 2018). Other studies in the literature report similar rates, such as investigations involving university students in Brazil (9.9\%) (Santos et al., 2017), the USA (12.1\%) (American College Health Association, 2018) and Colombia (31\%) (Macias \& Camargo, 2015), and also among adolescents in the USA (15.8\%) (Kaslow, 2014), Turkey (1.9\%) (Canbaz, 2018) and China (22.5\%) (Huang et al., 2020).

Only one of the primary studies (A1) (Jasso-Medrano \& Lopez-Rosales, 2018) employed a validated instrument (Positive and Negative Suicide Ideation Inventory: PANSI) (Osman et al., 1988) to determine the rate of suicidal ideation in university students. The PANSI contains 14 items, comprising 6 on positive suicidal ideation (protective factors) and 8 on negative suicidal ideation (risk factors), probing the frequency of each of these thoughts over the past 2 weeks. The inventory offers excellent reliability, with an internal consistency $>0.8$ according to the Cronbach's $\alpha$ reliability coefficient.

The other studies reviewed used self-administered instruments containing questions on suicidal ideation and suicide attempts (A2 and A3) (Poorolajal et al., 2019; Poorolajal et al., 2018), direct questions such as "Have you thought about committing suicide?" (A4) (Shen et al., 2020) or statements such as "Have you ever thought about suicide" with responses given on a Likert scale (A5) (Tsouvelas \& Giotakos, 2011).

A possible reason explaining the disparity in results of the different studies is the heterogeneity of the instruments used to screen for the presence of suicidal ideation in the students assessed by the studies included in this integrative review. The disparity in prevalence rates might also be related to differences in social and cultural backgrounds of the population groups studied. Another theory is that there may have been underreporting of the phenomenon, given the issue is typically associated with a social stigma. The fact that suicidal ideation was self-reported by participants might also have contributed to the differences in rates found.

Despite a large variety of instruments for analyzing suicidal thoughts and behaviors and their associated factors, few are designed specifically for use in younger individuals and adolescents, and there is no consensus for analyzing the scales in population-based studies (Silva \& Sougey, 2016). However, the importance of screening individuals at risk of suicide using validated reliable instruments that can help ascertain whether these thoughts constitute possible intentional acts to end one's life is clear.

A significant association between problematic internet use and suicidal ideation was found in all of the studies selected in this review, and likewise in other studies on adolescents conducted in Spain (Arrivillaga et al. 2020), China (Huang et al., 2020; Fu et al., 2010) and Korea (Park et al., 2012). However, after multiple logistic regression analysis, the association between suicidal ideating and problematic internet use was not statistically significant in 2 (A2 and A3) (Poorolajal et al., 2019; Poorolajal et al., 2018) of the 5 studies reviewed.

Given that internet addiction had been associated with multiple factors (depression, low family support, self-esteem, anxiety, and alcohol/drugs abuse, among others) and that these factors also increase the risk of suicide then, when co-occurring, they can contribute to the association between internet addiction and suicidal ideation (Lin et al., 2014). In addition, the internet represents an important source of information on suicide and its overuse can even assist vulnerable adolescents and young adults attempt to end their lives (Huang et al., 2020).

Although addictive behavior was found to be significantly related to suicidal ideation and depression (A1) (JassoMadrano \& Lopez-Rosales, 2018), a hypothetical model was analyzed using the equations modeling method to explain social media use addiction. In this case, addictive behavior can be considered a protective factor against suicidal ideation when relating to depression. A number of studies have been published showing a potential correlation between internet addiction, suicidal 
ideation and depression (Fu et al., 2014; Yen et al., 2007). Nevertheless, it is important to bear in mind that social networks can play a protective role against suicidal ideation by account of their key feature: promoting interaction among individuals (Chan et al., 2017; Cheng et al., 2015) and thus representing a source of emotional support to relieve psychological distress and to help develop coping strategies when depression symptoms are present (Bousono et al., 2017; Daine et al., 2013).

Another noteworthy finding of the present review is the significantly higher rates of suicidal ideation in internet addicts found in four (A1, A2, A4 and A5) (Jasso-Medrano \& Lopez-Rosales, 2018; Poorolajal et al., 2019; Shen et al., 2020; Tsouvelas \& Giotakos, 2011) out of the 5 studies reviewed. Previous studies have also shown a higher rate among addicted internet users compared with control subjects (Huang et al., 2020; Park et al., 2012), but dose-response relationships explaining this association were not explored in the South-Korean study (Park et al., 2012). However, a 2020 study published in China (Huang et al., 2020), involving 12,507 adolescents, mean age 16.6 years, which controlled for confounding effects, showed a dose-response relationship for this association, confirming that the higher the degree of internet addiction, the greater the presence of suicidal ideation among the adolescents.

Lastly, it is noteworthy that the 5 studies reviewed were cross-sectional in nature and hence measured both exposure and outcomes concomitantly. None of the studies ran open-ended interviews or focus groups in a qualitative approach aimed at elucidating the complex relationships and mediators potentially involved between excessive internet use and suicidal ideation. The main limitations of the present review include the dearth of studies with an emphasis on university students. The design of all 5 studies was cross-sectional and thus measured exposure and effects together, i.e. precluding the establishment of causal relationships. Moreover, none of the study authors employed open-ended interviews or focus groups that provided a qualitative approach to better understand the phenomenon investigated, pointing to the need for further studies exploring this issue. The heterogeneity of instruments used to determine the prevalence rates of internet addiction and suicidal ideation also may have contributed to the disparities in results found.

\section{Conclusion}

The results of this review showed a significant association between internet addiction and suicidal ideation in university students. However, this association was not significantly significant in all of the studies selected upon analysis by their authors using multivariate logistic regression methods. The rate of suicidal ideation in 4 out of the 5 studies reviewed was significantly higher in internet addicts. Although the presence of association does not indicate causality, these findings serve as an early warning sign to parents, educators and health professionals. The review also revealed the need for longitudinal studies to further elucidate this relationship.

The findings of this integrative review can help in devising psychological care and educational psychology treatment programs as part of a healthcare program for students and advance the knowledge in the health field.

\section{Acknowledgments}

To the Alagoas Research Support Foundation (FAPEAL) for the promotion of research.

\section{References}

American College Health Association. (2018). American College Health Association - National College Health Assessment II: Reference Group Executive Summary Fall 2017. https://www.acha.org/documents/ncha/NCHA-II_FALL_2017_REFERENCE_GROUP_EXECUTIVE_SUMMARY.pdf

American Psychiatric Association. (2013). Diagnostic and statistical manual of mental disorders (5th. ed.). Arlington, VA: American Psychiatric Publishing.

Arrivillaga, C., Rey, L. \& Extremera, N. (2020). Adolescents' problematic internet and smartphone use is related to suicide ideation: Does emotional intelligence make a difference? Computers in Human Behavior, 110, 106375. https://www.sciencedirect.com/science/article/abs/pii/S074756322030128X 
Bai, Yu \& Fan, Fu-mim. (2005). A study on the internet dependence of college students: The revising and applying of a measurement. Psychological Development and Education, 21(4), 99-104. http://www.devpsy.com.cn/EN/abstract/abstract707.shtml\#

Bisen, S. S. \& Deshpande, Y. (2020). Deshpande Y. Prevalence, predictors, psychological correlates of internet addiction among college students in India: a comprehensive study. Anadolu Psikiyatri Derg, 21(2), 117-123. https://www.bibliomed.org/mnsfulltext/91/apd_47328.pdf?1612729969

Bousoño Serrano, M., Al-Halabí, S., Burón, P., Garrido, M., Díaz-Mesa, E., Galván, G., García-Álvarez, L., Carli, V., Hoven, C., Sarchiapone, M., Wasserman, D., Bousoño, M., García-Portilla, M., Iglesias, C., Sáiz, P., \& Bobes, J. (2017). Uso y abuso de sustancias psicotrópicas e internet, psicopatología e ideación suicida en adolescentes. Adicciones, 29(2), 97-104. http://dx.doi.org/10.20882/adicciones.811

Brasil. Ministério da Saúde. (2012). Methodological guidelines: preparation of systematic review and meta-analysis of randomized clinical trials. http://bvsms.saude.gov.br/bvs/publicacoes/diretrizes_metodologicas_elaboracao_sistematica.pdf

Canbaz, S. \& Terzi, Ö. (2018). The Prevalence of Suicidal Ideation in Adolescents and Associated Risk Factors: an example from Turkey. Adv Ther, 35, 839846. https://doi.org/10.1007/s12325-018-0720-2

Cao, H., Sun, Y., Wan, Y., Hao, J. \& Tao, F. (2011) Problematic Internet use in Chinese adolescents and its relation to psychosomatic symptoms and life satisfaction. BMC Public Health, 11(1), 802. doi: 10.1186/1471-2458-11-802

Centers for Disease Control and Prevention. (2019). Violence prevention: risk and protective factors. USA. CDC. https://www.cdc.gov/violenceprevention/youthviolence/riskprotectivefactors.html

Centers for Disease Control and Prevention. (2018). Suicide Mortality in the United States, 1999-2017. NCHS Data Brief $\mathrm{n}^{\circ} 330$. USA. CDC. https://www.cdc.gov/nchs/products/databriefs/db330.htm

Chan, M., Li, T. M. H., Law, Y. W., Wong, P. W. C., Chau, M., Cheng, C., Fu, K., Bacon-Shone, J., Cheng, Q. \& Yip, P. (2017). Engagement of vulnerable youths using internet platforms. PLoS One, 12(12), e0189023. https://doi.org/10.1371/journal.pone.0189023

Chen, Z., Poon, K. T. \& Cheng, C. (2017). Deficits in recognizing disgust facial expressions and Internet addiction: perceived stress as a mediator. Psychiatry Research, 254, 211-217. https://www.sciencedirect.com/science/article/abs/pii/S0165178117300665

Cheng, Q., Li, T. M., KwoK, C-L., Zhu, T. \& Yip, P. S. F. (2015). Assessing suicide risk and emotional distress in Chinese social media: A text mining and machine learning study. J Med Internet Res, 19(7), e243. https://www.researchgate.net/publication/318333772_Assessing_Suicide_Risk_and_ Emotional_Distress_in_Chinese_Social_Media_A_Text_Mining_and_Machine_Learning_Study

Conti, M. A., Jardim, A. P., Hearst, N., Cordás, T.A., Tavares, H. \& Abreu, C. N. (2012). Evaluation of semantic equivalence and internal consistency of a Portuguese version of the Internet Addiction Test (IAT). Rev Psiq Clin, 39(3), 106-10. https://www.scielo.br/pdf/rpc/v39n3/en_a07v39n3.pdf

Daine, K., Hawton, K., Singaravelu, V., Stewart, A., Simkin, S. \& Montgomery, P. (2013). The power of the web: A systematic review of studies of the influence of the internet on self-harm and suicide in young people. PLoS One, 8(10), e77555. https://doi.org/10.1371/journal.pone.0077555

Fu, K. W., Chan, W. S. C., Wong, P. W. C. \& Yip, P. S. F. (2010). Internet addiction: Prevalence, discriminant validity and correlates among adolescents in Hong Kong. British Journal of Psychiatry, 196, 486-492. https://doi.org/10.1192/bjp.bp.109.075002

Fumero, A., Marrero, R. J., Voltes, D. \& Penate, W. (2018). Personal and social factors involved in internet addiction among adolescents: A meta-analysis. Computers in Human Behavior, 86, 387-400. https://www.sciencedirect.com/science/article/abs/pii/S0747563218302310

Greenfield, D. (2011). As propriedades de dependência do uso de internet. In: Young, K. S.; Abreu, C. N. Dependência de Internet. Manual e guia de avaliação e tratamento. ArtMed.

Ho, R. C., Zhang, M. W., Tsang, T. Y., Toh, A. H., Pan, F., Lu, Y., Cheng, C., Yip, P. S., Lam, L. T., Lai, C. M., Watanabe, H. \& Mak, K. K. (2014). The association between internet addiction and psychiatric co-morbidity: a meta-analysis. BMC psychiatry, 14, 183. https://doi.org/10.1186/1471-244X-14-183

Huang, Y., Xu, L., Mei, Y., Wei, Z., Wen, H. \& Liu, D. (2020). Problematic Internet use and the risk of suicide ideation in Chinese adolescents: A cross-sectional analysis. Psychiatry Res, 290: 112963. https://www.sciencedirect.com/science/article/abs/pii/S0165178120300433

IBOPE Inteligência. (2019). Youth and Connections / Telefonica Vivo Foundation; Social Knowledge Network (3ª ed.) São Paulo: Telefonica Vivo Foundation. http://fundacaotelefonicavivo.org.br/wp-content/uploads/pdfs/juventudes-e-conexoes-3edicao-completa.pdf

Internet World Stats. (2020). World internet usage and population statistics. https://internetworldstats.com/stats.htm

Internet World Stats. (2020). Internet Usage and Population in South America. https://www.internetworldstats.com/stats15.htm\#south

Jasso-Medrano, J. L. \& Lopez-Rosales, F. (2018). Measuring the relationship between social media use and addictive behavior and depression and suicide ideation among university students. Computers in Human Behavior, 87,183-91. https://www.sciencedirect.com/science/article/abs/pii/S0747563218302292

Kaslow, Nadine. Suicidal Bahavior in Children and Adolescents. (2014). Presentation of American Psychological Association. https://www.apa.org/about/governance/president/suicidal-behavior-adolescents.pdf

Kelley, K. J. \& Gruber, E. M. (2010). Psychometric properties of the Problematic Internet Use Questionnaire. Computers in Human Behavior, 26(6), 1838-1845. https://doi.org/10.1016/j.chb.2010.07.018

Kiersz, A. \& Akhtar, A. (2019). Suicide is Gen Z's second-leading cause of death, and it's a worse epidemic than anything millennials faced at that age. In Business Insider. https://www.businessinsider.com/cdc-teenage-gen-z-american-suicide-epidemic 
Kim, B. S., Chang, S. M., Park, J. E., Seong, S. J., Won, S. H. \& Cho, M. J. (2016). Prevalence, correlates, psychiatric comorbidities, and suicidality in a community population with problematic Internet use. Psychiatry 244, Research, https://www.sciencedirect.com/science/article/abs/pii/S016517811530130X?via\%3Dihub

King, A. L. S., Pádua, M. K., Guedes, E., Gonçalves, L. L., Guimarães, F. L., Dos Santos, H. K., Rodrigues, D. \& Nardi, A. E (2019). Scale to evaluate the abusive use of technologies. MedicalExpress, 6:mo19006. https://www.scielo.br/pdf/medical/v6/2358-0429-medical-06-mo19006.pdf

Kraut, R., Patterson, M., Lundmark, V., Kiesler, S., Mukopadhyay, T. \& Scherlis, W. (1998). Internet paradox. A social technology that reduces social involvement and psychological well-being? Am Psychol, 53(9), 1017-31. https://www.researchgate.net/publication/13445276_ Internet_Paradox_A_Social_Technology_That_Reduces_Social_Involvement_and_Psychological_Well-Being\#fullTextFileContent

Lin, I-H., Ko, C-H., Chang, Y-P., Liu, T-L., Wang, P-W., Lin, H-C., Huang, M-F., Yeh, Y-C. \& Chou W-J. (2014). The association between suicidality and Internet addiction and activities in Taiwanese adolescentes. Comprehensive Psychiatry, 55(3), 504-510. https://doi.org/10.1016/j.comppsych.2013.11.012

Lin, L. Y., Sidani, J. E., Shensa, A., Radovic, A., Miller, E., Colditz, J. B., Hoffman, B. L., Giles, L. M. \& Primack, B. A. (2016). Association between Social Media Use and Depression among U.S. Young Adults. Depress Anxiety, 33(4), 323-331. https://doi.org/10.1002/da.22466

Macías, E. F. S. \& Camargo, Y. S. (2015). Factores asociados a ideación suicida em universitarios. Psychol. av. discip, 9(1), 71-81. http://www.scielo.org.co/scielo.php?pid=S1900-23862015000100006\&script=sci_abstract\&tlng=es

Mayaute, M. E. \& Blas, E. S. (2014). Construcción y validación del cuestionario de Adicción a Redes Sociales (ARS). Liberabit, 20(1), 73-91. http://www.scielo.org.pe/pdf/liber/v20n1/a07v20n1.pdf

Melnyk, B. M. \& Fineout-Overholt, E. (2015). Evidence-based practice in nursing \& healthcare: a guide to best practice (3a ed.). Wolters Kluwer.

Mendes, K. D. S., Silveira, R. C.P. C. \& Galvão, C. M. (2008). Integrative literature review: a research method to incorporate evidence in health care and nursing. Texto Contexto Enferm, 17(4), 758-64. https://www.scielo.br/scielo.php?script=sci_arttext\&pid=S0104-07072008000400018

Monteiro, G. T. R. (2013). Pesquisa em Saúde Pública: como desenvolver e validar instrumentos de coleta de dados. Appris.

Moreno, M. A., Jelenchick, L. A. \& Christakis, D. A. (2013). Problematic internet use among older adolescents: A conceptual framework. Computers in Human Behavior, 29(4), 1879-1887. https://www.sciencedirect.com/science/article/abs/pii/S0747563213000563

Osman, A., Gutierrez, P. M., Kopper, B. A., Barrios, F. X. \& Chiros, C. E. (1998). The positive and negative suicide ideation inventory: development and validation. Psychological reports, 82(3 Pt 1), 783-793. https://doi.org/10.2466/pr0.1998.82.3.783

Park, S., Hong, K. E., Park, E. J., Ha, K. S. \& Yoo, H. J. (2013). The association between problematic internet use and depression, suicidal ideation and bipolar disorder symptoms in Korean adolescents. The Australian and New Zealand journal of psychiatry, 47(2), 153-159. https://doi.org/10.1177/0004867412463613

Picon, F., Karam, R., Breda, V., Restano, A., Silveira, A. \& Spritzer, D. (2015). We need to talk about technology: clinical characterization of the technology addiction subtypes. Rev. bras. Psicoter, 17(2), 44-60. http://rbp.celg.org.br/detalhe_artigo.asp?id=177

Poorolajal, J., Ahmadpoor, J., Mohammadi, Y., Soltanian, A. R., Asghari, S. Z. \& Mazloumi, E. (2019). Prevalence of problematic internet use disorder and associated risk factors and complications among Iranian university students: a national survey. Health Promotion Perspectives, 9(3), 207-13. https://www.ncbi.nlm.nih.gov/pmc/articles/PMC6717927/

Poorolajal, J., Mohammadi, Y., Soltanian, A. R. \& Ahmadpoor, J. (2018). The top six risky behaviors among Iranian university students: a national survey. Journal of Public Health, 41(4), 788-97. 10.1093/pubmed/fdy204

Santos, C. M. C., Pimenta, C. A. M. \& Nobre, M. R. C. (2007). The Pico strategy for the research question construction and evidence search. Rev Latino-Am Enfermagem, 15(3), 508-11. https://doi.org/10.1590/S0104-11692007000300023

Santos, H. G. B., Marcon, S. R., Espinosa, M. M., Baptista, M. N. \& Paulo, P. M. C. (2017). Factors associated with suicidal ideation among university students. Rev Latino-Am. Enfermagem, 25, e2878. https://doi.org/10.1590/1518-8345.1592.2878

Shen, Y., Meng, F., Xu, H., Li, X., Zhang, Y., Huang, C., Luo, X. \& Zhang, X. Y. (2020). Internet addiction among college students in a Chinese population: Prevalence, correlates, and its relationship with suicide attempts. Depression and anxiety, 37(8), 812-821. https://doi.org/10.1002/da.23036

Silva, T. P. S. \& Sougey, E. B. (2016). Suicide behavior assessment scales in adolescents in the general population. Rev. Bras. Pesq. Saúde, 18(3), 144-154. https://periodicos.ufes.br/index.php/rbps/article/view/15754

Silva, V. C. (2016). Validation and reliability of the Brazilian version of the Internet Dependency Test (IAT). (Master's Thesis) La Salle University Center. Canoas, Rio Grande do Sul. http://svr-net20.unilasalle.edu.br/handle/11690/692

Torrente, E., Piqueras, A., Orgiles, M. \& Espada, J. P. (2014). Association of Internet addiction with social anxiety and lack of social skills in Spanish adolescents. Ter. Psicol, 32. 175e184. https://pesquisa.bvsalud.org/portal/resource/pt/lil-734889

Tsouvelas, G. \& Giotakos, O. (2011). Internet use and pathological internet engagement in a sample of college students. Psychiatriki, 22(3), 221-30. https://www.researchgate.net/publication/51693514_Internet_use_and_pathological_internet_engagement_in_a_sample_of_college_students

Weinstein, A. \& Lejoyeux, M. (2010). Internet addiction or excessive internet use. Am J Drug Alcohol Abuse, 36(5), 277-83. 10.3109/00952990.2010.491880

World Health Organization. (2012). Public Health Action for Suicide Prevention: a structure. Geneve. http://site.cfp.org.br/wpcontent/uploads/2013/07/documento-suic\%C3\%ADdio-traduzido.pdf 
Research, Society and Development, v. 10, n. 6, e10810615505, 2021

(CC BY 4.0) | ISSN 2525-3409 | DOI: http://dx.doi.org/10.33448/rsd-v10i6.15505

Xin, M., Xing, J., Pengfei, W., Houru, L., Mengcheng, W. \& Hong, Z. (2018). Online activities, prevalence of Internet addiction and risk factors related to family and school among adolescents in China. Addictive Behaviors Reports, 7, 14-18. 10.1016/j.abrep.2017.10.003

Yen, J-Y., Ko, C-H., Yen, C. F., Wu, H-Y. \& Yang, M-J. (2007). The comorbid psychiatric symptoms of Internet addiction: Attention deficit and hyperactivity disorder (ADHD), depression, social phobia, and hostility. J Adolesc Health, 41(1), 93-98. https://doi.org/10.1016/j.jadohealth.2007.02.002

Younes, F., Halawi, G., Jabbour, H., El Osta, N., Karam, L., Hajj, A. \& Khabbaz (2016). Internet Addiction and Relationships with Insomnia, Anxiety, Depression, Stress and Self-Esteem in University Students: A Cross-Sectional Designed Study. Plos One 11(9). https://journals.plos.org/plosone/article?id=10.1371/journal.pone.0161126 